\title{
LEXEME OF KOREAN OFFICIAL LANGUAGE
}

\author{
Mohira Shermamat Kizi Jumayeva
}

Master's Student, Tashkent State University Of Oriental Studies Scientific Supervisor: Phd. Yunusova G.D., Uzbekistan

\section{ABSTRACT}

The article examines the vocabulary of Korean legislation, its general features, lexical units with common features used in legislation, methodological features, functions, lexical units that differ in their place in the formation of an official text, including methodically lexical units, neutral units of general speech and formal Special units in the status of basic units that logically and semantically form the text, are considered on the example of articles from the basic law of the Korean language.

KEYWORDS: - Vocabulary of official documents, basic law of the Korean language, official stereotypes, special vocabulary, narrows lexical units..

\section{INTRODUCTION}

It should be noted that in recent years, the lexical layer of the Korean language has been enriched with many new words, all functional styles of speech have been improved, and there have been significant changes in the use of words.

The lexicon of official documents in Korean has been formed over many years, and has undergone some changes and enrichment over time. We can observe the impact of formal cooperation, in particular, the rapid development of foreign relations, on the field of linguistics in two ways:

First, it has led to a significant increase and improvement in the types of official documents.
Second, it enriched the lexical layer in official documents (especially legislation).

As the scope of formal communication expanded, different lexical units were adopted into the lexicon of this style, or new lexical units were created using the internal capabilities of the language.

In the study of the lexicon of official documents in Korean, it is useful to distinguish methodological lexical units, their scope, and role in the formation of the text of working papers, thematic and structural types.

The layers of formal style vocabulary are different, depending on the content of the material, which is directly related to the specific extra-linguistic basis of each text. Therefore, each genre has its own 
CURRENT RESEARCH JOURNAL OF PHILOLOGICAL SCIENCES 2(12):

99-103, December 2021

DOI: https://doi.org/10.37547/philological-crjps-02-12-21

ISSN 2767-3758

(C2021 Master Journals

Crossref doi

81 Google

Accepted14 ${ }^{\text {th }}$ December, 2021 \& Published 19th December, 2021

stylistic features and standard tools [1, p. 157].

If we look at the lexicon of official documents in Korean, we can only see the units used in the documents, which means that not all lexical units can be used freely in the text of official documents.

\section{THE MAIN FINDINGS AND RESULTS}

In the lexicon of official documents, special lexical units are distinguished from other texts. They give the text of the document a formal look and remain in our minds in the form of a certain pattern. In particular, in Uzbek, I order, confirm, and so on, and in official Korean documents, such words as 목적으로 한다 (, 말한다emphasis added) 시행하여야 한다 can be found. In linguistics, in the text of official documents, there are officearisms, their essence; their importance in the formation of the text is noted. Consularisms are essential in compiling an official text [2, p. 31].

Reflecting on this, Professor Mahmudov states: "Formal business papers, in general, are words, phrases, and expressions that are often used in the style of office correspondence, and it is unthinkable to use them, and they have become a habit of writing in the same style. In linguistics, such units, which are called departmental words and phrases or clericalisms, are essential elements of the language of documents, because their formation significantly facilitates both the construction of speech and the rapid understanding of that speech" [3, pp. 131, 146].

The lexical units embedded in official documents are so semantically related to each other that they are associatively reminiscent of each other. As the Russian linguist Y.N. Karaulov points out, if any word does not exist in the human mind, memory, or in the same speech structures, it will strive for other words through dozens and hundreds of "threads"
[4, p. 191]; the lexical units associated with the formal style are not stored in the memory of the speakers. Such associative lexical units used in formal style texts are reminiscent not only of each other but also of a particular type of document.

In the texts of official documents in the Korean language, the use of neutral lexicon of general language lexicon is higher than the stylistic lexical layer. This layer includes lexical units that do not have a stylistic feature and are freely used in the style. For example: 삶, 목적, 생 각, 사용, 불 편 [5]. The following is a literal translation of some articles of the Basic Law of the Korean Language, focusing on their lexical features.

제 5 조(다른 법률과의 관계) 국어의 사용과 보급 등에 관하여 다른 법률에 특별한 규정이 있는 경우를 제외하고는 이 법에서 정하는 바에 따른 다.

[전문개정 2011.4.14.]

Translation:

Article 5 (Relation to other laws) The use and distribution of the Korean language shall be regulated by this Law, unless otherwise provided by other legislation.

[Full text edition 2011. 4. 14.]

The example shows that the lexical layer of this official Korean document consists of methodologically neutral words. Excessive units and repetitions are not allowed in the text. Lexical units are used selectively in the text, and each is focused on a specific task. In particular, words such as “사용, 특별한, 정하는" used in this article have both general and formal features.

제7조(시행계획의 수립 등) 문화체육관광부장관은 기본계획을 실천하기 위한 세부계획(이하 “시행계획”이라 한다)을 수립 - 시행하여야 한다.

(2) 문화체육관광부장관은 시행계획의 
CURRENT RESEARCH JOURNAL OF PHILOLOGICAL SCIENCES 2(12):

99-103, December 2021

DOI: https://doi.org/10.37547/philological-crjps-02-12-21

ISSN 2767-3758

(C2021 Master Journals

Crossref doi

81 Google

Accepted14th December, 2021 \& Published 19 ${ }^{\text {th }}$ December, 2021

수립·시행과 관련하여 필요한 경우 국가기관, 지방자치단체, 「공공기관의 운영에 관한 법률」에 따른 공공기관, 그 밖의 법률에 따라 설립된 특수법인(이하 “공공기관등”이라 한다) 중 관련 기관의 장에게 협조를 요청할 수 있다[5].

Translation:

Article 7 (preparation of the implementation plan, etc.) (1) The Minister of Culture, Sports and Tourism shall develop and implement a detailed plan for the implementation of the master plan (hereinafter referred to as the "implementation plan").

(2) The Minister of Culture, Sports and Tourism, in connection with the development and implementation of the implementation plan, if necessary, in accordance with the Law "On Management of Public Institutions", state bodies, local authorities, public authorities, as well as private corporations; may require the cooperation of the heads of relevant institutions established in accordance with other legislation (hereinafter referred to as "Government agencies, etc.").

In formal administration, some neutral units of general language vocabulary may in some cases be replaced by "special vocabulary" [2, p. 31]. This example is a piece of legislation that does not use pronouns, figurative words, modal expressions, figurative expressions, or phrases to describe people's emotional experiences. In general, such units are not observed in the text of official documents. It objectively reflected information as an official written medium that represented and recorded the attitude of the state and the people to language.

It should be noted that the formal style of work does not use figurative words, figurative words, and figurative expressions such as simile, animation, exaggeration, allegory, diagnosis, which are understood only by a narrow circle of people. Their use leads to inaccuracies in the wording of documents [6, p. 15].

제9조(실태 조사 등) (1) 문화체육관광부장관은 국어 정책의 수립에 필요한 국민의 국어능력, 국어 의식, 국어 사용 환경 등에 관한 자료를 수집하거나 실태를 조사할 수 있다.

(2) 문화체육관광부장관은 제 1 항에 따른 자료 수집이나 실태 조사를 위하여 필요한 경우에는 국가기관 및 국어 관련 법인 - 단체 등에 자료 제출이나 의견 진술 등을 요구할 수 있다.

(3) 국어능력, 국어 의식, 국어 사용 환경 등에 관한 실태 조사에 필요한 사항은 대통령령으로 정한다[5].

Translation:

Article 9 (Fact verification, etc.) (1) The Minister of Culture, Sports and Tourism may collect or verify information on the ability to speak Korean, the level of knowledge of the Korean language, the environment in which the Korean language is used, etc.

(2) The Minister of Culture, Sports and Tourism may, if necessary, collect information or establish facts in accordance with paragraph (1), and request information or opinions from national institutions, corporations and organizations related to the Korean language.

(3) The questions required for orientation education in Korean language, knowledge of Korean language, Korean language environment, etc. are determined by the Presidential Decree.

In this article, which is devoted to the definition of some lexical units used in the Korean language law, we can see the basic neutral lexicons: "국어능력, 국어 의식, 국어 사용 환경" and so on. The verb used in the article expresses the passive pronoun: "요구할 수 있다, 정한다". For example, special 
CURRENT RESEARCH JOURNAL OF PHILOLOGICAL SCIENCES 2(12):

99-103, December 2021

DOI: https://doi.org/10.37547/philological-crjps-02-12-21

ISSN 2767-3758

(C2021 Master Journals

Crossref doi

81 Google

Accepted14th December, 2021 \& Published 19 ${ }^{\text {th }}$ December, 2021

terms are rarely used, words denoting action content are few, and lexical units denoting nouns are predominant.

제 10 조(국어책임관의 지정) (1) 국가기관과 지방자치단체의 장은 국어의 발전 및 보전을

위한 업무를 총괄하는 국어책임관을 소속 공무원 중에서 지정하여야 한다. <개정 2017. 3. 21.>

(2) 제 1 항에 따른 국어책임관의 지정 및 임무 등에 관하여 필요한 사항은 대통령령으로 정한 다[5].

Translation:

Article 10 (Appointment of officials in charge of the Korean language).

(1) The heads of public institutions and local public authorities shall appoint an official in charge of the Korean language from among the public officials in their jurisdiction.

(2) The issues necessary for the appointment and performance of the duties of a Korean language specialist in accordance with paragraph (1) shall be determined by a presidential decree.

As a general feature of the articles in the Korean language, we can point out that before each article; the lexical units that indicate the meaning of the article are given in parentheses. This is a rare case in other language legislation. For example, Article 5 "다른 법률과의 관계" (related to other laws), Article 7 "시행계획의 수립 등” (determination of the implementation plan, etc.), Article 9 “실태 조사 등" (verification of facts and etc.), in Article 10, through lexical units such as "국어책임관의 지정" (appointment of officials in charge of the Korean language), the general content of these articles is given in parentheses before the main text.

When we discuss the basic law of the Korean language, we see a style of dealing with a narrow range of lexical items. In general, the use of the following tools is strictly prohibited in Korean law:

- Words with different forms and meanings, ie synonyms (if it is necessary to use terms of the same meaning, terms other than the main ones are written in parentheses);

- Neologisms (neologisms can be used in the text of some official documents, in which case its meaning is given in parentheses);

- Lexical units representing the evaluation relationship;

- Outdated words;

- Words specific to dialect;

- Euphemisms;

- Jargon and slang;

- Barbarism and parasitic words.

\section{Conclusion}

To conclude, the predominance of lexical units with a general linguistic character is observed in the legislation of the Korean language. Its lexical layer includes methodological units, functions, and units that differ in their role in the formation of formal text, including methodological lexical units, neutral units in general speech, and special units in the status of logical-semantic base units that form formal text.

\section{REFERENCES}

1. Boboyeva A. (1988) Formal style. - Tashkent. Fan. - p. 157.

2. Lutfullayeva D.E. (2020) Development of official-administrative style of work in the period of independence. Monograph. Tashkent. - p. 31.

3. Mahmudov N. (2007) Teacher speech culture. - Tashkent: National Library of Uzbekistan named after Alisher Navoi. - pp. 131, 146.

4. Karaulov Yu. N. (1994) Russian associative 
CURRENT RESEARCH JOURNAL OF PHILOLOGICAL SCIENCES 2(12):

99-103, December 2021

DOI: https://doi.org/10.37547/philological-crjps-02-12-21

ISSN 2767-3758

(C)2021 Master Journals

crossref do) :810 Google

Accepted14 ${ }^{\text {th }}$ December, 2021 \& Published 19th December, 2021

dictionary as a new linguistic source and tool for analyzing linguistic ability. Russian associative dictionary. Book 1. - Moscow. - p. 191.

5. 국어기본법. [시행 2020. 5. 27.] [법률 제 16589호, 2019. 11. 26., 일부개정]

6. Aminov M., Madvaliyev A., Mahkamov N., Mahmudov N. (2003) Record keeping. 2nd edition. - Tashkent: National Encyclopedia of Uzbekistan. - p. 15. 